\title{
A figura feminina nos retratos de Toulouse-Lautrec
}

\section{Caroline Heldes Oliveira (IC)}

\section{Resumo}

Esta pesquisa tem como objetivo, analisar como as transformações que ocorreram em Paris no final do século XIX e início do século XX, alterando as principais funções sociais e econômicas femininas, se relacionam com a obra do artista Henri de Toulouse-Lautrec (1864-1901).

Palavras Chave: Toulouse-Lautrec, feminismo, Belle Époque.

\section{Introdução}

A figura feminina sempre foi alvo de grande atenção entre os artistas e assumiu as mais diversas significâncias, sua imagem representou alegorias mundanas e divinas. No decorrer do tempo, as maneiras de representar e os temas relacionados à figura feminina mudam e isso está, muitas vezes, relacionado à mudanças sociais que afetam a parcela feminina da população.

No século XIX, por exemplo, a mulher não se resume mais às funções de esposa e mãe, ganha importância social e um lugar no mercado de trabalho.

O projeto visa verificar como esse fenômeno social se relaciona com as mudanças na maneira como a arte retrata a figura feminina, através dos retratos feitos pelo artista francês Henri de Toulouse-Lautrec.

\section{Resultados e Discussão}

Durante o desenvolvimento desta pesquisa ficou claro que o contexto histórico exerce grande influência sobre a arte produzida em sua época desde a pré-história, até mesmo sobre o que é legitimado como arte, como no caso da obra de Marcel Duchamp.

Surgiu então uma necessidade de investigar as condições sociais da mulher no decorrer da história diferenças de gênero que inferiorizaram o sexo feminino por séculos e, ainda mais, questionar a forma como a história foi escrita, em cenários onde os homens eram privilegiados.

As mudanças neste tópico devidas à atuação das mulheres no mercado de trabalho e na luta por maior autonomia política e econômica foram sim, determinantes para uma mudança, primeiramente na maneira como o sexo feminino se coloca e como é referenciado.

O período e local estabelecido para análise nesta pesquisa são muito pertinentes quando trata-se de feminismo, participação das mulheres no universo artístico e no desenvolvimento artístico onde a França é o centro cultural que concebe e exporta tendências artísticas para o resto do mundo. Neste cenário, ninguém melhor do que a figura de Toulouse-Lautrec - conhecida por retratar a vida boêmia parisiense em cartazes que eram espalhados pela cidade - para ser referência artística principal neste estudo. Seu trabalho foi reconhecido tanto nas ruas quanto dentro dos ilustres salões de arte de Paris.

\section{Conclusões}

A pesquisa confirmou que é muito difícil desvencilhar a arte do contexto histórico em que foi produzida e que ambos agem, um sobre o outro, criando uma relação direta. Mesmo tratando-se da história do gênero que foi, na maior parte do tempo, dominado, e portanto não tem-se um registro comprometido com questões especificamente femininas; o caso em estudo não configura uma exceção. A arte de ToulouseLautrec registra a partir de um olhar muito próximo, o processo de desconstrução da imagem submissa na qual a mulher foi calcada por séculos, através da luta por direitos civis e independência do gênero masculino, sobretudo em relação às questões econômicas.

\section{Agradecimentos}

É apropriado agradecer, primeiramente, ao orientador desta pesquisa, o Prof. Dr. Paulo Mugayar Kühl e ao Programa Institucional de Bolsas de Iniciação Científica (PIBIC)/CNPq, que possibilitou o desenvolvimento desta pesquisa por meio da Bolsa de Iniciação Científica.

WEBER, Eugen. França, Fin de Siècle. $1^{\mathrm{a}}$ reimpressão. São Paulo, SP: Editora Schwarcz, 1989.

2 MONTEIRO, Dulcinéa da Mata Ribeiro. Mulher: feminino plural: mitologia, história e psicanálise. Rio de Janeiro, RJ: Record: Rosa dos Tempos, 1998.

${ }^{3}$ HANSON, Lawrence; HANSON, Elisabeth (Coaut. de). A vida de Toulouse Lautrec. Lisboa: Estudios Cor, 1958. 265p. 